\author{
Asian Journal of \\ Medical and Biological Research \\ ISSN 2411-4472 (Print) 2412-5571 (Online) \\ www.ebupress.com/journal/ajmbr
}

\title{
Article \\ Study of the climate change impact on fishers' livelihood near the Padma river in Munshiganj, Bangladesh
}

\author{
Noore Safa Ema, Md. Saddam Hossain, Md. Nagim Uddin, Mohammad Matiur Rahman and Zakir Hossain* \\ Department of Fisheries Biology and Genetics, Bangladesh Agricultural University, Mymensingh-2202, \\ Bangladesh \\ *Corresponding author: Zakir Hossain, Department of Fisheries Biology and Genetics, Faculty of Fisheries, \\ Bangladesh Agricultural University, Mymensingh-2202, Bangladesh. Phone: +8801724-939693; Fax: +88091- \\ 61510; E-mail: zakir.fbg@ bau.edu.bd
}

Received: 05 December 2020/Accepted: 27 December 2020/ Published: 31 December 2020

\begin{abstract}
Climate change is a contemporary global threat to the whole world especially in the coastal area like Bangladesh. Bangladesh is extremely vulnerable to climate change impacts because of its geographical location. This research is an attempt to assess the impacts of climate change on fishers' livelihood of a selected climate hotspot zone Munshiganj. In the study area, the average sex ratios of male and female were $56.67 \%$ and $43.33 \%$, respectively and their religion ratio were Islam $45 \%$ and Hindu 55\%. There was $60 \%$ nuclear family and $40 \%$ joint family. About $86.4 \%$ house was tin-shed and drinking water source was only tube well. In Munshiganj, $11 \%$ fishers were illiterate, $27 \%$ had primary, $38 \%$ had secondary, $16 \%$ had higher secondary and $8 \%$ had bachelor. Most of the people about 59\% were depended on Upazila Health Complex for their health issues. Highest percentage of fishers about $40 \%$ had an annual income of 20,001 to 24,000 BDT. About $62.7 \%$ fishers were agreed with the statements: reduce fish production, damage fishing ground, blockage of fish migration road, damage biodiversity, increasing temperature, enhance soil erosion, reduce rainfall, siltation, water flow, storm frequency, changing spawning season, decrease fish production, extinction fish species. In study area, women and children are affected severely i.e. malnutrition, education, treatment, early marriage etc. The present study clearly indicates that there are visible changes in livelihood condition of fishers' in the study areas of Munshiganj.
\end{abstract}

Keywords: climate change; education; economical condition; fishers; livelihood

\section{Introduction}

Climate change has now become a much-discussed issue in the world and it also affects the global environmental system. Global warming is expected to cause changes such as higher temperatures, sea level rise and changing rainfall patterns, as well as more abrupt effects, such as an increase in the intensity and frequency of extreme events such as floods, storm surges, cyclones, and salinity intrusion may drastically cause enormous devastations to flora and fauna in Bangladesh (Lara et al., 2011). Bangladesh deals with the effects of climate change because of the all too loud alarm bells sounded in recent times about the dangers to which the least developed countries of the world are exposed. Climate-related factors will result in losing the means of livelihood of 40 million people in Bangladesh, with the additional fact of 20 million more being displaced by 2050 owing to natural calamities generated by climate change. About one thousand million people (100 crore) of the world will lose their habitat (be the destitute) by the year 2050. Now, one severe effect of climate change will be people getting uprooted from their land and finding themselves in the unenviable position of having turned into climate refugees. Climate change arises from past and present emissions of greenhouse gases increasing pre-existing concentrations of these gases in the atmosphere (IPCC, 2007a). Following the industrial revolution, humans have increasingly relied on fossil fuels as an energy source. Currently, about $80 \%$ of the 
world's power is generated from fossil fuels (ACIA, 2004). The International Panel on Climate Change Assessment Report predicts that global average temperature is expected to increase by $0.2^{\circ} \mathrm{C}$ per decade over the next two decades. If temperature continues to increase at this rate, it adds, global average temperature increase (from 1905) will reach $1.5^{\circ} \mathrm{C}$ by 2050 (IPCC, 2007b). For example, the concentration of atmospheric carbon dioxide is now higher than any observed in the last 160,000 years (Dobson, 2001). However, the climate has very complex relationships with the seasonality including variations of temperature, rainfall and day length (Gill and Gerard, 1991). Such seasonal variation has a diverse influence on physicochemical conditions of water, fishing, fish production and Fishers' livelihoods (Hossain et al., 2018; Tumpa et al., 2020). The variation in the global climate or in regional climate over time, such as variations in sunlight intensity, droughts, greenhouse gas emission, temperature rise, extreme temperature, unexpected rainfall, floods and cyclones, arsenic contamination, losses of the ecosystem which caused by processes of internal and external forces (WFC, 2009).

The Padma river is one of the major rivers in Bangladesh and plays an economic important role in the national economy and it also supports a great portion of fisheries resources and fishers' livelihood. It plays a significant role in nutrient recycling and serves as a favorable breeding and nursing grounds for many commercially important fishes. Fishers' community is considered as one of the most backward sections in our country. Fishers' livelihood is affected by changes of climate that are ultimately driven by rising global temperatures. In Munshiganj district, Padma River carries many charlands which are vulnerable to climate change. Charlands' fishers in Bangladesh face increased frequency and severity of cyclones with severe penetration of saline water into the river due to thermal expansion of the warming Bay of Bengal, the people of the Munshiganj districts converge around the Padma river, as regional warming drives decreased rainfall and increased evapotranspiration (Coe and Folley, 2001), set within a context of overexploitation of the fisheries resources (Mullon et al., 2005). Although the Padma river has high importance of fisheries resources for fishers but there is no comprehensive report on the effects of climate change on livelihood of the fishers in these rivers. The impacts of climate change cover comprehensive aspects of rural livelihoods, there is a critical challenge to understand the broad significance to fisheries resource and livelihood status with climate change and to concentrate on people's needs to build their resilience. Therefore, the results of the present study were undertaken to evaluate the impacts of climate change on the livelihood of the fishers' communities around the Padma river and help to take the necessary steps in maintaining their better livelihood pattern.

\section{Materials and Methods}

\subsection{Profile of the study area}

The study was conducted in Louhajang Upazila in Munshiganj district (Figure 1). Louhajang is located at $23.4667^{\circ} \mathrm{N}$ and $90.3417^{\circ} \mathrm{E}$ and it has a total area of $130.12 \mathrm{~km}^{2}$. The main study zone was the charlands of Louhajang near the Padma River.

\subsection{Primary data collection}

To inquire into the livelihood of fishers and the impact of climate change on them, a total of 120 fishers in each area were interviewed by the structured questionnaire at their houses, boats, markets and local areas. The questionnaire included the questions on the socio-demographic conditions like age, sex, religion, marital status, family members, types of family, education, house status, sanitary facilities, medical facilities, drinking water sources, current facilities, land status, safety and security etc. It has also included socio-economic questions like income sources, daily or monthly income, loan facilities, amount of loan, amount of interest (\%), source of loan, savings and Government and NGOs facilities etc.

\subsection{Secondary data collection}

Data derive from a large study on fishers' communities that collated observations of climate change impacts and adaptive response by fishers of Munshiganj. Here "observation" means a primary observation either cited or stated in the source material by individuals or groups who are identified as subsistence-oriented fishers (i.e., fishers depending on the fishery for subsistence) (Savo et al., 2016). This definition retrenches observations from modern commercial fishers as well as secondary assessments from researchers (i.e., impacts assessed by researchers in fishers' communities) (Savo et al., 2017).

\subsection{Data arrangement}

All observations were collocated into four groups: changes in weather and climate, changes in the physical components of the environment, changes in the fisheries resources and impacts on well-being of fishers' 
specially women and children. Further, all four groups e.g., changes in weather and climate, changes in the physical components of the environment, changes in the fisheries resources and impacts on well-being of fishers specially women and children were sub-classified into 8, 7,11 and 15 sub-groups, respectively. Each sub-group was evaluated as rare, occational, high, moderately high and extremely high event through ranking within 1 to 5 categories which was determined by the rate of the frequency of occurrence of each event in the study area.

\subsection{Data analysis and map building}

The collected fishers data consistent from the study areas were analyzed with the tenets of grounded theory so as to detect and clarify emergent patterns rather than rely on prior assumptions (Glaser and Strauss, 2012) and then presented in textual and graphical forms to understand the impact of climate change on fishers' livelihood status as well as the constraints of fisher folks. GIS software consisted of an interface from MapInfo and digitized maps from ArcGIS 10.5. Other statistical data were analyzed using Microsoft office 10 and SPSS and then presented in textual and graphical forms.

\section{Results and Discussion}

\subsection{Demographic information of the fishers in Louhajang, Munshiganj}

The basic information of the fishers is represented in Table 1. It is seen that average household size of the fishers was 5.0 and average dependency ratio was 2.13 in fishers' community. In the study area, the average sex ratio of male and female were $56.67 \%$ and $43.33 \%$, respectively. Islam et al. (2020a) found $76.67 \%$ male and $23.23 \%$ female in Kishoregonj Haor region. The age group of below 15 to 60 years which is considered as active and working group in the fishers' community and their religion ration were Islam $45 \%$ and Hindu 55\% (Table 1). According to Shill et al. (2016), 80\% fishers were Hindu in Munshiganj. But according to Islam et al. (2020a) Muslims are dominant in Haor region in Kishoreganj. Most of the fishers have nuclear family (60\%) and few have joint family (40\%). During this study period, fishers are considered as permanent (65\%) and temporary (35\%) fishers. In fishers' community, the average children number was 3 . Most of house was tinshed house (86.4\%) and drinking water source was tube well (100\%). In Shill et al. (2016) most (58\%) of the houses were found 'Kacha' near Padma river. Most of the fishers were used semi hygienic sanitation type (92.40\%), only $7.60 \%$ fishers were used unhygienic sanitation. Rahaman et al. (2020) reports that 59\%, 13\%, $21 \%$ and $7 \%$ of fishers used tin-shed, semi-cemented, cemented and open toilet respectively at Chandpur and 52\%, 26\%, 16\% and 6\% at Patuakhali region. According to Ali et al. (2009) found that $62.5 \%$ of the fishers had semi-cemented, $25 \%$ had tin-shed and $12.5 \%$ had cemented toilet at Tarakanda Upazila of Mymensingh district. The average fishing activity time was $12 \mathrm{hr}$ /day and only $73.33 \%$ fishers' community get benefits of electricity (Table 1).

\subsection{Educational level of fishers in Louhajang, Munshiganj}

Fishers were categorized into five categories on the basis of the level of education. Out of 100 fishers, $11 \%$ had no education, $27 \%$ had primary level, $38 \%$ had secondary level, $16 \%$ had higher secondary level and $8 \%$ had bachelor level of education at Munshiganj (Figure 2). Shill et al. (2016) found that $14 \%$ of the fishers near Padma river were totally illiterate, $24 \%$ can sign only, $20 \%$ got primary education, and the rest $22 \%$ got secondary and higher secondary education. According to Sunny et al. (2019), 41\% Hilsa fishers of Char Atra of Padma River were totally illiterate, $46 \%$ had primary education, $9 \%$ had secondary level education, $2 \%$ had higher secondary and $2 \%$ completed graduation. According to Rahaman et al. (2020) primary, secondary education levels were highest at Chandpur and Patuakhali. Zaman et al. (2006) reported that $23.3 \%$ fishers were illiterate at Mohanpur Upazila in Rajshahi District.

\subsection{Natural and financial capital of fishers in Louhajang, Munshiganj}

Natural capital of fishers involved in fishing represent the natural resources such as land, open water, fish availability, soil type, and wider environmental goods that are critical for fishers and associated groups to support production. Large areas of land, water and natural resources had been used for high fish production. Rapid population growth had to some extent led to accelerate natural capital depletion that had affected their income. It was found that $24 \%$ received loan from different NGOs, $47 \%$ of the fishers used their own money for fishing, $17 \%$ borrow from relatives and $12 \%$ of the fishers borrow from neighbors at Munshiganj (Figure 3). Rahaman et al. (2020) found that $41 \%$ fishers received loan from different NGOs, $32 \%$ of the fishers used their own money for fishing, $17 \%$ borrow from relatives and $10 \%$ of the fishers borrow from neighbors at Chandpur and 38\% received loan from different NGOs, $29 \%$ self-dependent, $21 \%$ from relatives, $12 \%$ from neighbors at Patuakhali region. Mahmud et al. (2015) reports that $30 \%$ were self-sufficient but $24 \%$ borrow money from 
their neighbors, $22 \%$ from relatives, $16 \%$ from NGO's and $8 \%$ from co-operatives for their fishing business of Paira river, Patuakhali.

\subsection{Health facilities of fishers in the study area of Louhajang, Munshiganj}

Health facilities of the fishers were poor and it was found that $59 \%$ of the fishers were dependent on Upazila health complex, $30 \%$ on village doctors and $11 \%$ on MBBS (Bachelor of Medicine, Bachelor of Surgery) doctors respectively at Louhajang, Munshiganj (Figure 4). According to Rahaman et al. (2020) 57\% fishers were dependent on Upazila health complex, $27 \%$ on village doctors and $16 \%$ on registered physicians in Chandpur and $46 \%$ fishers on upazila health complex, $45 \%$ on village doctor and $9 \%$ on registered physicians at Patuakhali. In Sreenagar, Munshiganj $46 \%$ of fishers go to the village doctor/Kobiraj, $18 \%$ to Upazila health complex, $14 \%$ go to the district hospital and $20 \%$ of fishers go to MBBS doctor (Shill et al., 2016). According to Pravakar et al. (2013) in the Shahrasti Upazila, most of them (70\%) are dependent on village doctors, while $20 \%$ and $10 \%$ got health service from Upazila health complex and MBBS doctors respectively.

\subsection{Annual income of fishers in Louhajang, Munshiganj}

The annual income of fishers was varied from 20,000 to 50,000 BDT. The selected fishers were grouped into four categories based on the level of their annual income (Table 2). The highest percentage (40\%) fishers earned BDT 20,001 to 24,000 per year (Table 2). In the fishers' community of the Padma River, $47 \%$ fishers' annual income was ranging from Tk. 50,000-60,000 (Akther et al., 2017). According to Rahaman et al. 2020, 44\% of fishers earned 20,080 to 24,000 BDT per year at Chandpur and 46\% at Patuakhali. The annual income of fishers ranged from 60,000 to 85,000 BDT in the areas of Turag-Buriganga river in Dhaka (Baki et al., 2015).

\subsection{Fishers' perceptions about the impact of climate change in Munshiganj}

Fishers' perceptions about the impact of climate change on their day-to-day life were evaluated using agreement index (AI). Fishers observations were recorded on impact of climate change on 15 statements, and their depth of agreements on the selected statements were calculated consequently. Table 3 showed that $70 \%$ fishers of the study areas were agreed with the statements about reduce fish production, damage fishing ground, blockage of fish migration road, damage biodiversity, increasing temperature, enhance soil erosion, reduce rainfall, siltation, water flow, storm frequency, changing spawning season, decrease fish production, extinction fish species. However, $30 \%$ fishers were disagreed with the statements.

Climate change affects the distribution, health and survival of aquatic organisms and river water fluctuation also depend on the season, geographic location and climatic factors (Rahaman et al., 2019; Islam et al., 2020b). Islam et al. (2020a) reports that about $87.5 \%$ fishers said that flash flood was the most vulnerable problem in the Kishoreganj Haor area. Chowdhury et al. (2010) reported that Bangladesh is highly vulnerable in fisheries due to the effects of climate change.

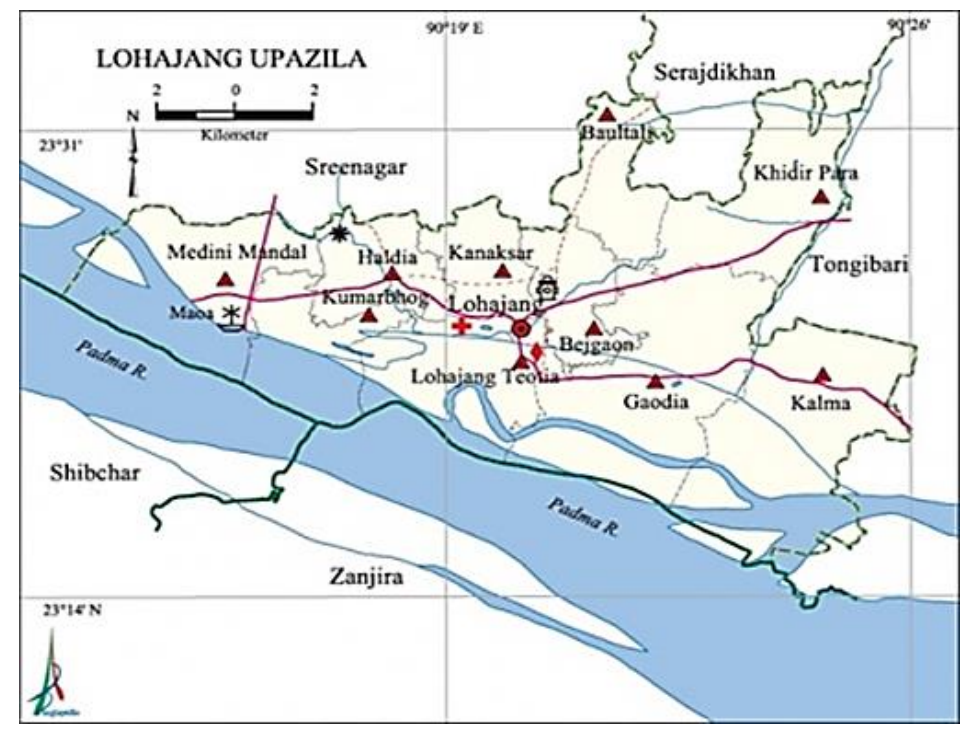

Figure 1. Map showing the study areas Louhaganj, Munshiganj. 


\section{Educational level}

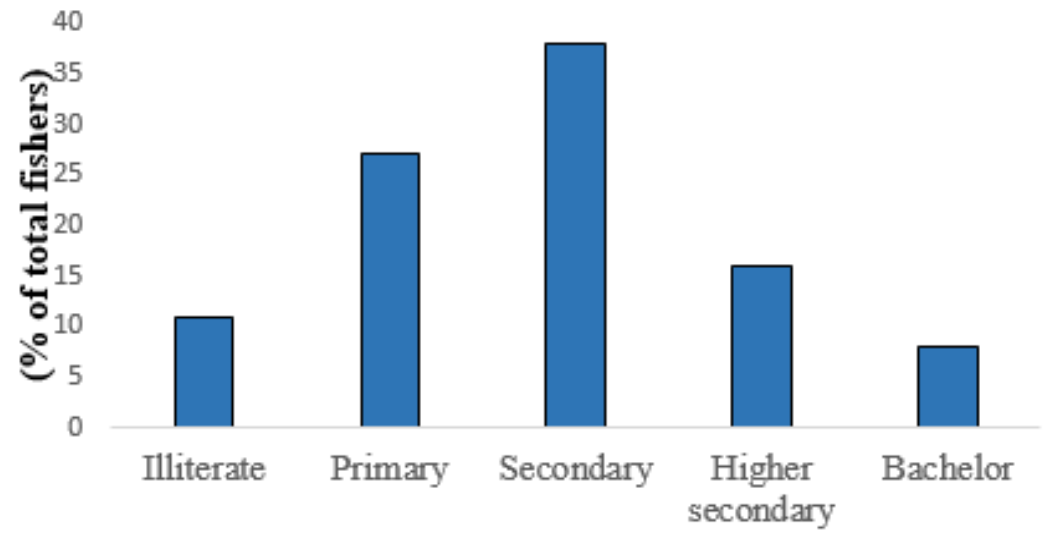

Figure 2. Educational level of fishers in the study area of Munshiganj.

\section{Credit access of the fishers}

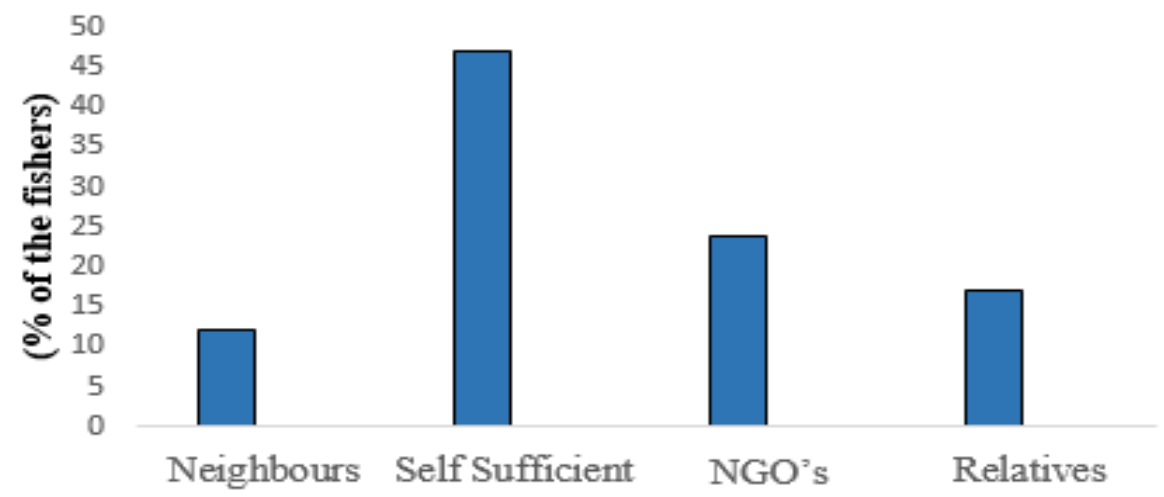

Figure 3. Credit access of the fishers in the study area of Munshiganj.

\section{Health Facilities}

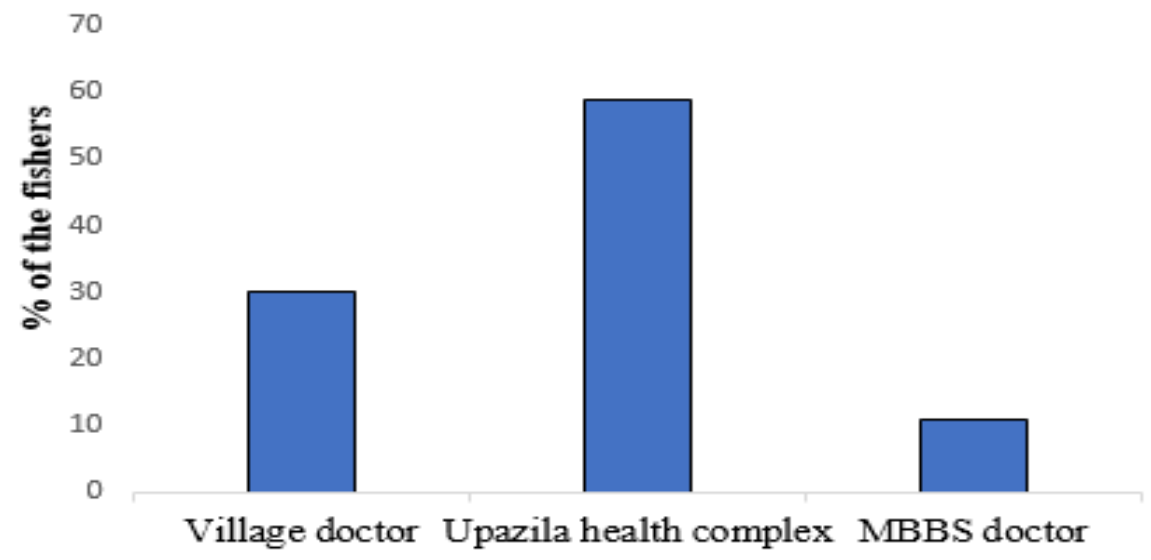

Figure 4. Health facilities of fishers in the study area of Louhajang, Munshiganj. 
Asian J. Med. Biol. Res. 2020, 6 (4)

Table 1. Basic information about the fishers in Louhaganj, Munshiganj.

\begin{tabular}{|c|c|c|}
\hline \multicolumn{2}{|l|}{ Particulars } & Percentages of fishers \\
\hline \multicolumn{2}{|c|}{ Average household size (no.) } & 5.00 \\
\hline \multicolumn{2}{|c|}{ Average dependency ratio (no.) } & 2.13 \\
\hline \multirow{2}{*}{ Average sex distribution } & Male & 56.67 \\
\hline & Female & 43.33 \\
\hline \multirow{4}{*}{ Average age } & Below 15.00 years & 9.17 \\
\hline & 15.01 to 30.00 years & 32.50 \\
\hline & 30.01 to 45.00 years & 39.17 \\
\hline & 45.01 to 60.00 years & 19.17 \\
\hline \multirow{2}{*}{ Religion } & Islam & 45.00 \\
\hline & Hindu & 55.00 \\
\hline \multirow{2}{*}{ Marital status } & Unmarried & 19.17 \\
\hline & Married & 80.83 \\
\hline \multirow{2}{*}{ Family type } & Nuclear family & 60.00 \\
\hline & Joint family & 40.00 \\
\hline \multirow{2}{*}{ Average children (no.) } & Male & 1.70 \\
\hline & Female & 1.30 \\
\hline \multirow{3}{*}{ Occupational status } & Fishing only (with licence) & 34.17 \\
\hline & Fishing only (without licence) & 36.67 \\
\hline & Fishing and others & 39.17 \\
\hline \multirow{2}{*}{ Fishers type } & Permanent & 65.00 \\
\hline & Temporary & 35.00 \\
\hline \multirow{2}{*}{ Housing condition } & Muddy house & 13.60 \\
\hline & Tin-shed & 86.40 \\
\hline \multirow{3}{*}{ Source of drinking water } & Pond & 0.00 \\
\hline & Own tube well & 46.00 \\
\hline & Others tube well & 54.50 \\
\hline \multirow{2}{*}{ Sanitation type } & Unhygienic & 7.60 \\
\hline & Semi- hygienic & 92.40 \\
\hline \multicolumn{2}{|c|}{ Average fishing time (hr/day) } & 12.00 \\
\hline \multicolumn{2}{|l|}{ Electricity facilities } & 73.33 \\
\hline
\end{tabular}

Table 2. Annual incomes of fishers in the study area of Munshiganj.

\begin{tabular}{ll}
\hline Annual Incomes (BDT) & Percentage (\%) \\
\hline Up to 20,000 & 26 \\
$20,001-24,000$ & 40 \\
$24,001-30,000$ & 26 \\
$>50,000$ & 8 \\
\hline
\end{tabular}


Table 3. Agreement index regarding the impacts of climate change.

\begin{tabular}{|c|c|c|c|}
\hline \multirow{2}{*}{ Statements } & \multicolumn{2}{|c|}{ Fishers agreement } & \multirow{2}{*}{ Weights } \\
\hline & Agreed & Disagreed & \\
\hline Reduce fish production & $84 / 120$ & $36 / 120$ & $1 / 15$ \\
\hline Damage fishing ground & $77 / 120$ & $53 / 120$ & $1 / 15$ \\
\hline Blockage fish migration route & $75 / 120$ & $45 / 120$ & $1 / 15$ \\
\hline Damage biodiversity & $81 / 120$ & $39 / 120$ & $1 / 15$ \\
\hline Increase cost of fishing materials & $86 / 120$ & $34 / 120$ & $1 / 15$ \\
\hline Increase temperature & $78 / 120$ & $52 / 120$ & $1 / 15$ \\
\hline Enhance soil erosion & $67 / 120$ & $53 / 120$ & $1 / 15$ \\
\hline Reduce rainfall & $77 / 120$ & $43 / 120$ & $1 / 15$ \\
\hline Siltation and sedimentation & $69 / 120$ & $51 / 120$ & $1 / 15$ \\
\hline Change water flow level & $76 / 120$ & $49 / 120$ & $1 / 15$ \\
\hline Storm Severity & $96 / 120$ & $24 / 120$ & $1 / 15$ \\
\hline Storm frequency & $86 / 120$ & $34 / 120$ & $1 / 15$ \\
\hline Change spawning season & $68 / 120$ & $52 / 120$ & $1 / 15$ \\
\hline Decrease fish reproduction & $87 / 120$ & $33 / 120$ & $1 / 15$ \\
\hline Extinct fish species & $80 / 120$ & $40 / 120$ & $1 / 15$ \\
\hline Index score & 0.627 & 0.373 & - \\
\hline Depth of agreement (\%) & 62.7 & 37.3 & - \\
\hline
\end{tabular}

Source: Authors' estimation based on field survey, 2017-2018. (Modified from Uddin et al., 2017).

Note: Calculation of index score for agreed opinions $=(77 / 120 \times 1 / 15)+(67 / 120 \times 1 / 15)+(73 / 120 \times 1 / 15)+(81 / 120 \times$ $1 / 15)+(86 / 120 \times 1 / 15)+(68 / 120 \times 1 / 15)+(62 / 120 \times 1 / 15)+(77 / 120 \times 1 / 15)+(69 / 120 \times 1 / 15)+(71 / 120 \times 1 / 15)+$ $(96 / 120 \times 1 / 15)+(86 / 120 \times 1 / 15)+(63 / 120 \times 1 / 15)+(87 / 120 \times 1 / 15)+80 / 120 \times 1 / 15)=0.627$

Calculation of index score for disagreed opinions $=(43 / 120 \times 1 / 15)+(53 / 120 \times 1 / 15)+(47 / 120 \times 1 / 15)+(39 / 120 \times 1 / 15)$ $+(34 / 120 \times 1 / 15)+(52 / 120 \times 1 / 15)+(58 / 120 \times 1 / 15)+(43 / 120 \times 1 / 15)+(51 / 120 \times 1 / 15)+(49 / 120 \times 1 / 15)+(24 / 120 \times$ $1 / 15)+(34 / 120 \times 1 / 15)+(57 / 120 \times 1 / 15)+(33 / 120 \times 1 / 15)+(40 / 120 \times 1 / 15)=0.373$

Calculation of depth of agreement for agreed opinions $=0.627 \times 100=62.7 \%$

Calculation of depth of agreement for disagreed opinions $=0.373 \times 100=37.3 \%$

\section{Conclusions}

In the present study, Climate change affected the livelihood of the fishers near the Padma river in Munshiganj. The livelihood conditions of the fishers in the Padma river area were not satisfactory. Due to climate change, fishers' communities are facing many serious problems such as diseases, lack of food, lack of land, lack of economic support and lack of other facilities. Flood, storm surge and soil erosion were common in the Munshiganj region. Climate change is a challenge for the fishers' community in the Munshiganj region. So it is necessary to conduct an awareness training programme to improve management of environmental risk and adaptive capacity.

\section{Acknowledgements}

Authors acknowledge to the Project Implementation Unit, National Agricultural Technology Program-Phase II Project (NATP-2), Bangladesh Agricultural Research Council (BARC), Farmgate, Dhaka-1215, Bangladesh for funding the project (no. CRG-718).

\section{Conflict of interest}

None to declare.

\section{References}

ACIA, 2004. Impacts of a warming arctic: Climate impact assessment. Cambridge university press.

Akther S, GS Sankar, H Akther and MN Islam, 2017. Livelihood Strategies of Riverine Fishing Communities of the River Padma near Rajshahi City Corporation. Int. J. Fish. Aquat. Stud., 5(2): 195-199.

Ali H, MAK Azad, M Anisuzzaman, MMR Chowdhury, M Hoque and MI Sharful, 2009. Livelihood status of the fish farmers in the fish farmers in some selected areas Tarakanda upazila of Mymensingh district. J. Agroforest. Environ., 3: 85-89.

Allison and A Mead, 1998. Geologic Framework and Environmental Status of the Ganges-Brahmaputra Delta. J. Coast. Res., 13 (3): 826-836. 
Baki MA, MR Islam, MM Hossain and NA Bhouiyan, 2015. Livelihood status and assessment of fishing community in adjacent areas of Turag-Burigonga river, Dhaka, Bangladesh. Int. J. Pure Appl. Zool., 3: 347353.

Bolin B, BR Döös, J Jager and RA Warrick, 1986. The greenhouse effect. Climatic Change and Ecosystems. John Wiley and Sons, Chichester, UK.

Chowdhury MSH, MM Rahman, M Koike, N Muhammed, KM Salahuddin, MA Halim and MJ Islam, 2010. Small-scale mehedi (Lawsoniainermis L.) farming in the central Bangladesh: a promising NTFP-based rural livelihood outside the forests. Small Scale Forest., 9: 93-105.

Coe TM and FA Jonathan, 2001. Human and natural impacts on the water resources of the Lake Chad basin. J. Geophys. Res., 106: 3349-3356.

Dobson DM, 2001. From ice cores to tree rings. In: Spray SL, McGlothlin KL (eds) Global climate change. Rowman and Littlefield Publishers, Inc., Oxford, UK. 31-58.

Ficke AD, CA Myrick and LJ Hansen, 2007. Potential impacts of global climate change on freshwater fisheries. Rev. Fish Biol. Fish., 17: 581-613.

Gill GJ and J Gerard, 1991. Seasonality and agriculture in the developing world: A problem of the poor and the powerless. Cambridge university press.

Glaser B and A Strauss, 2012. The discovery of grounded theory: Strategies for qualitative research, 7th edn. Piscataway: Aldine Transaction. comprehensive changes in marine benthic communities. Ecology. 85: 18331839.

Hossain J, MJ Sarker, MN Uddin, A Islam, IJ Tumpa and Z Hossain, 2018. Macrobenthos presence in the estuarine waters of the Meghnariver, Ramghati, Laksmipur, Bangladesh. World Appl. Sci. J., 36: 598-604.

IPCC, 2007a. The Physical Science Basis. Contribution of Working Group I to the Fourth Assessment Report. International Panel on Climate Change, 4.

IPCC, 2007b. Impacts, adaptation and vulnerability: contribution of Working Group II to the fourth assessment report of the Intergovernmental Panel on Climate Change. Cambridge University Press.

Islam A, MS Hossain and Z Hossain, 2020a. Impacts of climate change on fishers' livelihood in Kishoregonj Haor region, Bangladesh. Asian J. Med. Biol. Res., 2020. 6: 408-417.

Islam A, SS Basak and Z Hossain, 2020b. Fish and plankton biodiversity in the Kishoreganj haor, Kishoreganj, Bangladesh. Gene. Aquat. Org., 4: 39-48.

Mahmud S, ML Ali and MM Ali, 2015. Present scenario on livelihood status of the fishers in the paira river, southern Bangladesh: constraints and recommendation. Int. J. Fish. Aquat. Stud., 2: 23-30.

Mann ME, RS Bradley and MK Hughes, 1998. Global-scale temperature patterns and climate forcing over the past six centuries. Nature. 392: 779-787.

Mullon C, P Fréon and P Cury, 2005. The dynamics of collapse in world fisheries. Fish Fish., 6: 111-120.

Pravakar P, BS Sarker, M Rahman and MB Hossain, 2013. Present status of fish farming and livelihood of fisherman in Shahrasti Upazila of Chandpur District, Bangladesh. Am- Eurasian J. Agric. Environ. Sci., 13: 391-397.

Rahaman MJ, MS Hossain, MM Rahman and Z Hossain, 2020. Impacts of climate change on livelihood of the fishers' at the Meghna, Laukhati and Galachipariver in Bangladesh. Asian J. Med. Biol. Res., 6: 81-92.

Rahaman MJ, NS Ema, MS Hossain, MM Rahman and Z Hossain, 2019. Effects of climate change on fisheries biodiversity of the Meghna, Laukhati and Galachipa river in Bangladesh. Eurasia J. Biosci., 13: 1705-1717.

Savo V, C Morton and D Lepofsky, 2017. Impacts of climate change for coastal fishers and implications for fisheries. Fish Fish., 18: 877-889.

Savo V, D Lepofsky, JP Benner, KE Kohfeld, J Bailey and K Lertzman, 2016. Observations of climate change among subsistence-oriented communities around the world. Nat. Clim. Chang., 6: 462.

Shill S, A Sarker, M Asaduzzaman, GA Latifa, SC Podder and MA Obaida, 2016. Livelihood Status of Fishers of The Padma River, Sreenagar, Munshiganj. Bangladesh J. Zool., 44: 41-50.

Sunny AR, GS Ahamed, MH Mithun, MA Islam, B Das and A Rahman, 2019. Livelihood Status of The Hilsa (Tenualosa ilisha) Fishers: The Case of Coastal Fishing Community of The Padma River, Bangladesh. J. Coast Zone Manag., 22: 469.

Tumpa IJ, MS Hossain, MN Uddin and Z Hossain, 2020. Spawning and developmental biology of endangered Pabdah catfish, Ompok pabda (Hamilton, 1822). Asian J. Med. Biol. Res., 6: 449-459.

WFC, 2009. Vulnerability of national economies to the impacts of climate change on fisheries. Fish Fish., 10: 173-196.

Zaman T, MAS Jeweland and AS Bhuiyan, 2006. Present status of livelihood of the fisherman of Mohanpur Upazila in Rajshahi District. Univ. J. Zool. Rajshahi , 25: 31-35. 